[Agr. Biol. Chem., Vol. 35, No. 5, p. 734 742, 1971]

\title{
Biochemical Studies on Rice Bran Lipase
}

\section{Part I. Purification and Physical Properties}

\author{
By Masaru Funatsu, Yasuo Aizono, Katsuya Hayashi, \\ Masayoshi WATANABE and Masakazu ETo \\ Laboratory of Biochemistry, Faculty of Agriculture, \\ Kyushu University, Fukuoka, Japan \\ Received October 7, 1970
}

\begin{abstract}
Lipase extracted from defatted rice bran with calcium chloride solution was purified by ammonium sulfate precipitation, followed by successive column chromatographies on DEAE-cellulose, Sephadex G-75, CM-Sephadex C-50 in the presence of calcium ion. The specific activity of the purified enzyme was 4.7 units/mg protein and 480 times that of starting crude extract. The homogeneity of the enzyme protein was criticized by polyacrylamide gel disc electrophoresis and ultracentrifugation. The enzyme protein also behaved homogeneously in ampholine electrophoresis, indicating the isoelectric point of 8.56. The sedimentation coefficient of the enzyme was determined to be $2.97 \mathrm{~S}$, and the molecular weight to be 40,000 by Archibald's method. According to the measurement of optical rotatory dispersion of the enzyme, ORD constant, $\lambda_{c}$, Moffitt-Yang parameters, $a_{0}$ and $b_{0}$, were evaluated to be $239 \mathrm{~m} \mu,-164$ and -123 , respectively.
\end{abstract}

Several lipases of animal origin, especially pancreas lipase, have been purified and their chemical and enzymatic properties were elucidated in detail. ${ }^{12}$ As to lipase of microbial origin, Fukumoto et al., ${ }^{31}$ for instance, crystallized a preparation of lipase obtaind from Asp. niger as a single protein. In contrast, studies on lipases in higher plant have advanced slowly, probably due to their solubilities and diversities. The existence of lipase in higher plant was first noticed by Green $^{4}$ in castor bean in 1890 . Since then, the castor bean lipase has been investigated most intensively among the higher plant

1) P. Desnuelle, "Advances in Enzymology," Vol. 23 , ed. by F, F. Nord, Interscience Pub. Inc., New York, 1961, p. 129.

2) R. Verger, G. H. Haas, L. Sarda and P. Desnuelle, Biochim. Biophys. Acta, 188, 272 (1969).

3) J. Fukumoto, M. Iwai and Y. Tsujisaka, $J$. Gen. Appl. Microbiol., 9, 353 (1963).

4) J.R. Green, Pro. Roy. Soc. London, 48, 370 (1890). lipases, because of its relatively high activity. ${ }^{5 \sim 8\}}$ With respect to rice bran lipase, Kimura ${ }^{9}$ studied the hydrolysis of lipids by crude enzyme preparation, and Noda and Kobayashi ${ }^{101}$ examined the enzymatic properties of a partially purified enzyme preparation. Although these studies yielded appreciable informations on the enzymatic properties of the rice bran lipase, physical and chemical properties of the enzyme were not elucidated at all. The present paper, therefore, deals

5) E. Takamiya, Nippon Nogeikagaku Kaishi, 11, 68,216 (1935).

6) R. L. Ory, A. J. St. Angelo and A. M. Altschul, J. Lipid Res., 1, 208 (1960); ibid., 3, 99 (1962).

7) R. L. Ory, A.J. St. Angelo, I. V. deGruy and A. M. Altschul, Can. J. Biochem., 45, 1445 (1967).

8) R. L. Ory, J. Kiser and P. A. Pradel, Lipids, 4, 261 (1969).

9) G. Kimura, Yukagaku, 9, 154, 365, 486 (1960); ibid, 10, 136, 248 (1961).

10) M. Noda and K. Kobayashi, Nippon Nogeikagaku Kaishi, 42, 574 (1968). 
mainly with the purification of the rice bran lipase for the purpose of investigating the physical properties of the enzyme.

\section{MATERIALS AND METHODS}

Materials. Rice bran used throughout this study was prepared from grains of "Hohyoku," one of japonica varieties, produced in Fukuoka prefecture in 1968.

All reagents used were of analytical grade except the followings. Tributyrin used as substrate in enzyme assay was purchased from Merk Co. Carrier ampholites ( $\mathrm{pH} 7 \sim 10$ ) was obtained from LKB-Produkter $A B$, collodion membrane filter from Sartorius-Membranefilter $\mathrm{GmbH}$, DEAE-cellulose $(0.8 \sim 1.0 \mathrm{meg} / \mathrm{g})$, from Brown Co., and CM-Sephadex C-50 (4 $\sim 5 \mathrm{meg} / \mathrm{g})$, Sephadex G-75 from Pharmachia Co.

Enzyme assay. The lipase activity was assayed by adding $0.2 \mathrm{ml}$ of tributyrin to an enzyme solution consisted of $0.1 \mathrm{ml}$ of $0.5 \mathrm{M} \mathrm{KCl}, 1.0 \mathrm{ml}$ of $5 \times 10^{-3} \mathrm{M}$ $\mathrm{CaCl}_{2}$, and a given amount of the enzyme. The final volume of the reaction mixture was made up to $10 \mathrm{ml}$ with deionized water. The enzyme reaction was carried out at $\mathrm{pH} 7.5$ and $35^{\circ} \mathrm{C}$ with constant stirring under nitrogen gas stream, unless otherwise mentioned. The increase in free fatty acid produced in consequence of the enzyme reaction was followed by titraction with either 0.05 or $0.1 \mathrm{~N} \mathrm{NaOH}$ by using a pH-Stat (Radiometer Type TTT-1C).

Enzyme unit. The international unit was employed: one lipase unit was defined as the amount of enzyme that hydrolyzes one $\mu$ mole of ester bond in triglyceride per minute. The specific activity was expressed as the enzyme unit per $\mathrm{mg}$ of enzyme protein.

Determination of protein concentration. Protein concentration was determined spectrophotometrically with = Beckman DU spectrophotometer by using the value $E_{280, \mathrm{em}}^{1 \%}=19.67$.

Polyacrylamide gel disc electrophoresis. The pure enzyme preparation was subjected to disc electrophoresis in polyacrylamide gel prepared according to the method of Reisfeld et al.11 The electrophoresis was carried out for $3.5 \mathrm{hr}$ at approximate $110 \mathrm{~V}$

11) R. A. Reisfeld, U. J. Lewis and D. E. Williams, Nature, 195, 281 (1962). with a current of $2.5 \mathrm{~mA} /$ tube $(7 \mathrm{~cm} \times 0.5 \mathrm{~cm})$ using $0.35 \mathrm{M} \quad \beta$-alanine-acetate buffer $(\mathrm{pH} \quad 4.5)$. Protein band in gel was detected by staining with Amide Black $10 \mathrm{~B}$, followed by removing unbound dye with several changes of $7 \%$ acetic acid $(\mathrm{v} / \mathrm{v})$.

Ampholine electrophoresis. A lyophilized enzyme preparation (1.7 $\mathrm{mg}$ ) was applied to an ampholine electrophoresis in $0.8 \%$ carrier ampholytes $(\mathrm{pH} \mathrm{7 \sim}$ 10) medium containing $1 \times 10^{-3} \mathrm{M} \mathrm{CaCl}_{2}$. Electrophoresis was conducted using electrofocusing column, LKB 8101 , for $50 \mathrm{hr}$ at $2^{\circ} \mathrm{C}$ with about 1.1 Watt throughout the electrophoresis. After contents of the column were fractionated into $1.5 \mathrm{ml}$-portions, the amount of enzyme protein in each portion was determined spectorophotometrically at $280 \mathrm{~m} \mu$, and each $\mathrm{pH}$ value was measured by a Hitachi-Horiba $\mathrm{pH}$ meter equipped with glass electrode $6028-10 \mathrm{~T}$ at $25^{\circ} \mathrm{C}$.

Sedimentation analysis. Measurements of sedimentation velocity were made at five 8 -min intervals by a Spinco Model E Ultracentrifuge equipped with a schlieren optical system and a synthetic boundary cell, operating at $56,100 \mathrm{rpm}$ at $20.6^{\circ} \mathrm{C}$. The solvent employed was a solution of $1 \times 10^{-3} \mathrm{M} \mathrm{CaCl}_{2}$ in phosphate buffer, $\mathrm{pH} 6.2$.

Ultraviolet absorption spectrum. The ultraviolet absorption spectrum was determined wtih a Cary Model 14 Recording Spectrophotometer. The sample solution contained $0.441 \mathrm{mg}$ of enzyme protein per $1 \mathrm{ml}$ of $0.01 \mathrm{M}$ phosphate buffer containing $1 \times 10^{-3} \mathrm{M}$ $\mathrm{CaCl}_{2}$.

Determination of molecular weight. The molecular weight of the enzyme protein was determined with Archibald's method ${ }^{12,13)}$ by using a Spinco Model E Ultracentrifuge equipped with a schlieren optical system. The enzyme solution at a concentration of $70 \%$ in phosphate buffer $(\mu=0.1)$, pH 6.1, was ultracentrifuged by using a standard cell at $13,410 \mathrm{rpm}$ at $20^{\circ} \mathrm{C}$. The initial concentration was measured with synthetic boundary cell under the same conditions as described above. The molecular weight was calculated according to the following equation.

12) W.J. Archibald, J. Phys. and Colloid Chem., 51, 1204 (1947).

13) H. K. Schachman, "Methods in Enzymology," Vol. IV, ed. by S.P. Colowick and N. O. Kaplan, Academic Press Inc., New York, 1957, p. 32. 


$$
M=\begin{array}{cc}
R T \\
(1-V \rho) \omega^{2}
\end{array} \cdot \begin{aligned}
& (d c / d x)_{m} \\
& X m \cdot C m
\end{aligned}=\begin{array}{cc}
R T & (d c / d x)_{b} \\
(1-V \rho) \omega^{2} & X b \cdot C b
\end{array}
$$

where $R$ is the gas constant, $T$ the absolute temperature, $V$ the partial specific volume of enzyme protein (assumed to be 0.75 ), $\rho$ the density of enzyme solution, $\omega$ the angular velocity, $X m$ and $X b$ are the distance from the center of rotation to meniscus and bottom, $C m$ and $C b$ are the solute concentration at meniscus and bottom. $C m$ and $C b$ were determined according to the method reported by Klainer et al. ${ }^{14}$

Optical rotatory dispersion measurement. Optical rotatory dispersion measurement was performed with a Jasco Model ORD/UV-5 Recording Spectropolarimeter at room temperature near $25^{\circ} \mathrm{C}$. For the measurement in the visible and near ultraviolet region $(600 \sim 300 \mathrm{~m} \mu), 10 \mathrm{~mm}$-cell was used with the enzyme solution at a concentration of $1.23 \%$. The deionized water was used as solvent. The value of $\lambda_{c}$ was calculated by Drude's equation (1) and the values of $a_{0}$ and $b_{0}$ by Moffitt-Yang's equation (2), ${ }^{15}$

$$
\begin{aligned}
& {[\alpha]_{\lambda}=\begin{array}{c}
K \\
\lambda^{2}-\lambda_{c} c^{2}
\end{array}} \\
& {[M]_{\lambda}=\begin{array}{cl}
3 & M_{0} \\
n^{2}+3 & 100
\end{array}[\alpha]_{\lambda}=\begin{array}{c}
a_{0} \lambda_{0}^{2} \\
\left(\lambda^{2}-\lambda_{0}^{2}\right)
\end{array}+\begin{array}{c}
b_{0} \lambda_{0}{ }^{4} \\
\left(\lambda^{2}-\lambda_{0}^{2}\right)^{2}
\end{array}}
\end{aligned}
$$

where $M_{0}$ is the average molecular weight per residue, $\lambda_{0}$ the absorption wavelength concerned with the rotation and $n$ the solvent refractive index. In the present work, $M_{0}$ of $110, \lambda_{0}$ of $210 \mathrm{~m} \mu$ and $n$ of 1.335 were used.

\section{RESULTS AND DISCUSSION}

\section{A. Purificalion of enzyme}

Extraction of lipase from rice bran (Step I). The rice bran was defatted five times with petroleum ether. The defatted rice bran was then suspended in $1 \times 10^{-2} \mathrm{M}$ calcium chrolide and adjusted to $\mathrm{pH} 6.0$ with $1 \mathrm{~N} \mathrm{NaOH}$. After mechanical stirring for $3 \mathrm{hr}$, the suspension was squeezed through cheese cloth and the turbid solution was centrifuged for $20 \mathrm{~min}$

14) S. M. Klainer and G. Kegels, Arch. Biochem. Biophys., 63, 247 (1956).

15) W. Moffitt and J. T. Yang, Pro. Natl. Acad. Sci. U.S., 42, 596 (1956). at $5000 \mathrm{rpm}$. A slightly turbid supernatant was obtained and designated as "crude extract",

Fractionation with ammonium sulfate (Step II). To the crude extract was added solid ammonium sulfate to $60 \%$ saturation under constant stirring. The resulting precipitate was separated by centrifugation and then suspended in a minimum amount of $1 \times 10^{-3} \mathrm{M} \mathrm{CaCl}_{2}$. The suspension was dialyzed against the same solution at $4^{\circ} \mathrm{C}$ for 2 days. Insoluble material was removed by centrifugation. The clear supernatant was designated as "crude enzyme solution"

$D E A E$-cellulose column chromatography (Step III). The crude enzyme solution was dialyzed against $0.005 \mathrm{M}$ phosphate buffer containing $1 \times 10^{-3} \mathrm{M} \mathrm{CaCl}_{2}, \mathrm{pH} 7.0$, at $4^{\circ} \mathrm{C}$ for 3 days. After removal of any insoluble material by centrifugation, $5 \mathrm{ml}$ (106.9 $\mathrm{mg}$ enzyme) of the supernatant was applied onto a DEAE-cellulose column previously equilibrated with the same buffer solution as that used for dialysis. Elution was carried out stepwise with $0.005,0.02$, $0.06,0.1 \mathrm{M}$ phosphate buffer containing $1 \times 10^{-3} \mathrm{M}$ $\mathrm{CaCl}_{2}, \mathrm{pH} 7.0$ and finally with $0.1 \mathrm{M}$ phosphate buffer ( $\mathrm{pH} 7.0$ ) containing $1 \mathrm{M} \mathrm{NaCl}$ additionally to $1 \times 10^{-3} \mathrm{M} \mathrm{CaCl}_{2}$. As shown in Fig. 1, protein was separated to six fractions. The fraction D-1, which exhibited the highest specific activity was collected and reprecipitated by saturation with ammonium sulfate. On the other hand, $5 \mathrm{ml}$ (102.6 mg enzyme) of the crude enzyme solution, which was obtained by the similar purification procedures in the absence of calcium chloride, was chromatographed on DEAE-cellulose column in the same way as above using buffer solution without $\mathrm{CaCl}_{2}$. As shown in Fig. 2, protein was separated similarly as above. However, each fraction exhibited more or less enzyme activity and the specific activity of the fraction $D^{\prime}-1$ was about one half that of the fraction D-1. Thus, procedures with calcium chloride was proved to be of great advantage 


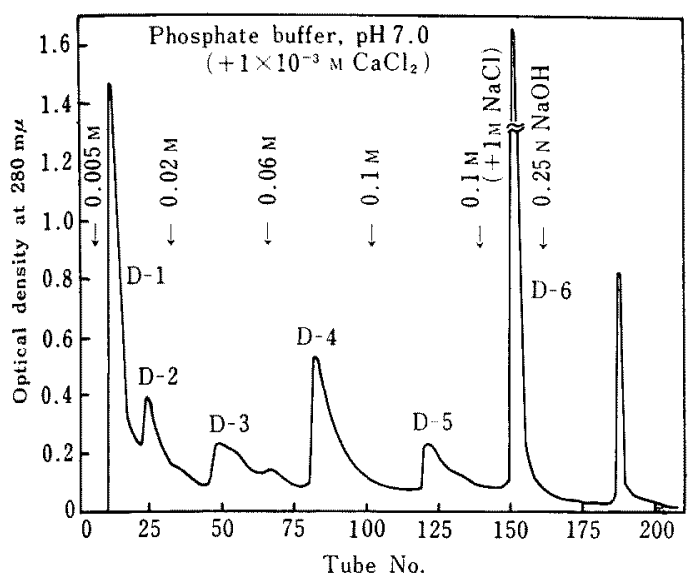

Frg. I. Column Chromatogram of Crude Enzyme on DEAE-cellulose in the Presence of $\mathrm{CaCl}_{2}$.

Column size; $2 \times 20 \mathrm{~cm}$, Content of each tube; $5.3 \mathrm{ml}$, Flow rate; $80 \mathrm{ml} / \mathrm{hr}$.

Total recovery of protein: $97 \%$.

Total recovery of activity: 96,6 .

Specific activities ( $\mathrm{mU} / \mathrm{mg}$ ) of fractions: D-1: 290.8, D-2: 41.3, D-3: 53.2, D-4: 29.5, D-5: 26.6, D-6: 17.7 .

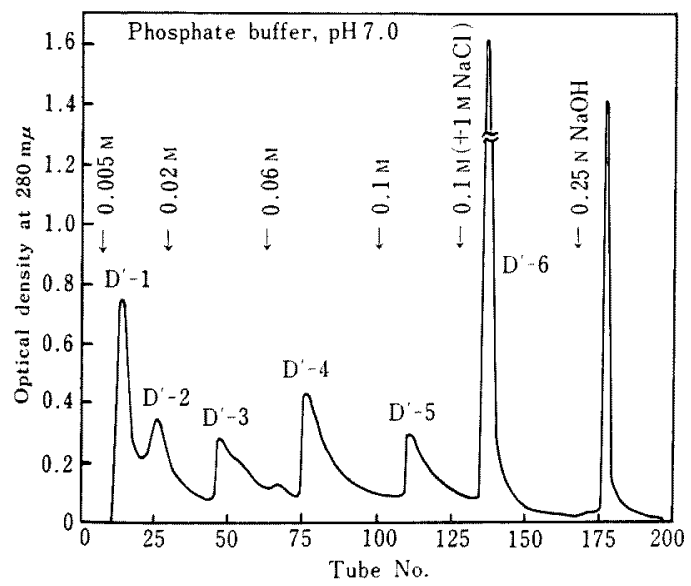

Fig. 2. Column Chromatogram of Crude Enzyme on DEAE-cellulose in the Absence of $\mathrm{CaCl}_{2}$.

Column size; $2 \times 20 \mathrm{~cm}$, Content of each tube; $5.3 \mathrm{ml}$, Flow rate; $80 \mathrm{ml} / \mathrm{hr}$.

Total recovery of protein: $92 \%$.

Total recovery of activity: $95 \%$.

Specific activities ( $\mathrm{mU} / \mathrm{mg}$ ) of fractions: $D^{\prime}-1$ : 104.2, $\mathrm{D}^{\prime}-2: 67.8, \mathrm{D}^{\prime}-3: 64.8, \mathrm{D}^{\prime}-4: 52.2, \mathrm{D}^{\prime}-5:$ $36.4, \mathrm{D}^{\prime} \cdot 6: 17.7$. to the purification of the enzyme.

Gel-filtration on Sephadex G-75 (Step IV). The precipitate obtained in Step III was dissolved in $0.01 \mathrm{M}$ phosphate buffer ( $\mathrm{pH} 6.2$ ) containing $1 \times 10^{-3} \mathrm{M} \mathrm{CaCl}_{2}$ and dialyzed against the same buffer solution for 2 days. After removal of any insoluble material by centrifugation, $25 \mathrm{ml}$ ( $679.7 \mathrm{mg}$ enzyme) of the dialyzed solution was separated through a Sephadex G-75 column previously washed sufficiently with the same phosphate buffer. A typical gel filtration pattern is presented in Fig. 3. The fraction

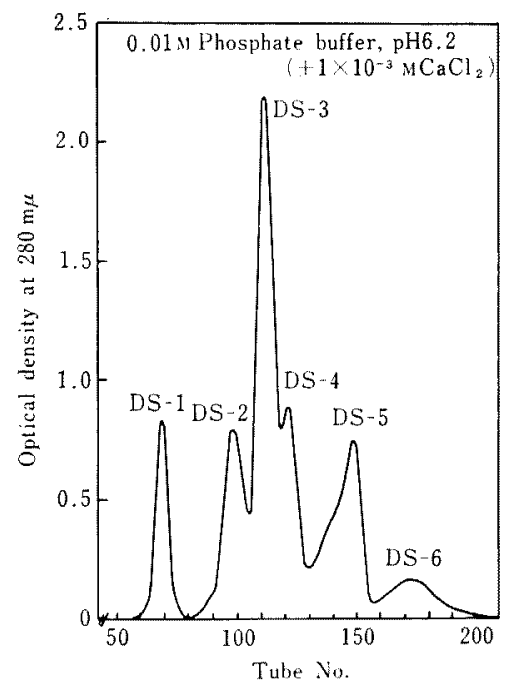

FIG. 3. Gel-filtration Pattern of Fraction D-1 on Sephadex G-75.

Column size; $5 \times 115 \mathrm{~cm}$, Content of each tube; $10.5 \mathrm{ml}$, Flow rate; $90 \mathrm{ml} / \mathrm{hr}$.

Total recovery of protein: $98 \%$.

Total recovery of activity: $96 \%$

Specific activities ( $\mathrm{mU} / \mathrm{mg}$ ) of fractions: DS-I: 66.8, DS-2: 237.8, DS-3: 407.2, DS-4: 306.7, DS-5: 31.4, DS-6: 0 .

DS-3 with the highest specific activity was concentrated using collodion membrane filter under reduced pressure.

CM-Sephadex C-50 column chromatography (Step $V)$. Six $\mathrm{ml}$ (309 $\mathrm{mg}$ enzyme) of the con- 


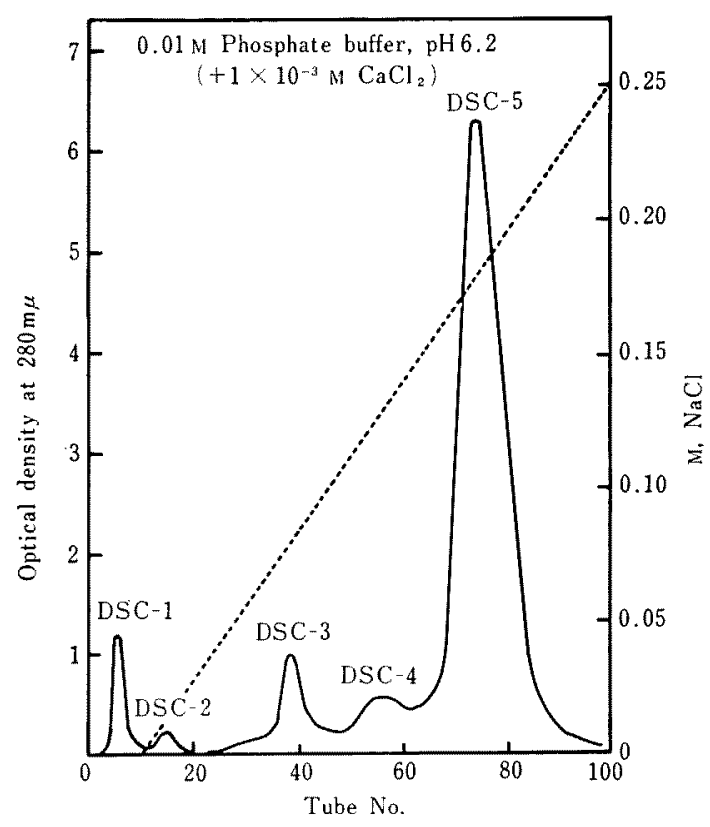

FIG. 4. Column Chromatogram of Fraction DS-3 on CM-Sephadex C-50.

Column size; $2 \times 19 \mathrm{~cm}$, Content of each tube;

$6.3 \mathrm{ml}$, Flow rate; $50.4 \mathrm{ml} / \mathrm{hr}$.

Total recovery of protein: $98 \%$.

Total recovery of activity: $96 \%$.

Specific activities ( $\mathrm{mU} / \mathrm{mg}$ ) of fractions: DSC-I: 561, DSC-2: 1908, DSC-3: 2949, DSC-4: 1402, DSC-5: 63 .

centrated enzyme solution in Step IV was applied onto a CM-Sephadex C-50 column previously equilibrated with $0.01 \mathrm{M}$ phosphate buffer containing $1 \times 10^{-3} \mathrm{M} \mathrm{CaCl}_{2}, \mathrm{pH} \quad 6.2$. The enzyme adsorbed on the column was eluted with a linear gradient change of the concentration of $\mathrm{NaCl}$ from 0 to $0.25 \mathrm{M}$ by using a mixing chamber containing $300 \mathrm{ml}$ of $0.01 \mathrm{M}$ phosphate buffer ( $\mathrm{pH} 6.2$ ) and $1 \times 10^{-3} \mathrm{M}$ $\mathrm{CaCl}_{2}$ and a reservoir containing $300 \mathrm{ml}$ of the same buffer and $0.25 \mathrm{M} \mathrm{NaCl}$. A typical column chromatogram is presented in Fig. 4. The fraction DSC-3 which showed the highest specific activity among five peaks was collected and concentrated using collodion membrane filter under reduced pressure.
Rechromatography on the CM-Sephadex C-50 column (Siep VI). The concentrated enzyme solution in Step V was dialyzed against $0.01 \mathrm{M}$ phosphate buffer containing $1 \times 10^{-3} \mathrm{M} \mathrm{CaCl}_{2}$ to remove $\mathrm{NaCl}$. Four $\mathrm{ml}$ (146.9 mg enzyme) of the dialyzed enzyme solution was applied onto a CM-Sephadex C-50 column which had been equilibrated with the same buffer solution as used for dialysis. The column was developed by linear gradient elution with a mixing chamber which contained $450 \mathrm{ml}$ of $0.01 \mathrm{M}$ phosphate buffer and $1 \times 10^{-3} \mathrm{M} \mathrm{CaCl}_{2}$ and a reservoir which contained $450 \mathrm{ml}$ of $0.15 \mathrm{M} \mathrm{NaCl}$ in the same buffer. As can be seen in Fig. 5, four peaks were obtained. The fraction RDSC-3 exhibited the highest specific activity. The lipase contained in the fraction RDSC-3 was behaved homogeneously on CM-Sephadex C-50 column chromatography as obviously seen in Fig. 6. The steps of the

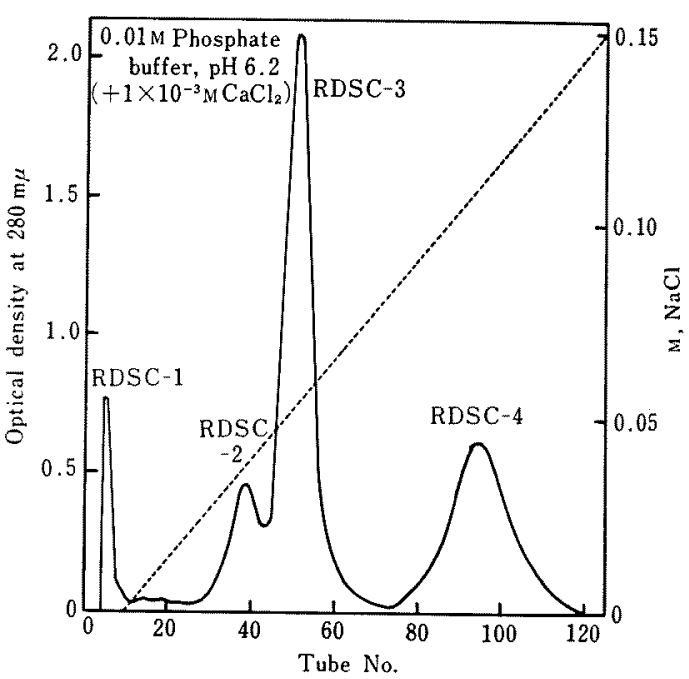

FIG. 5. Column Chromatogram of Fraction DSC-3 on CM-Sephadex C-50.

Column size; $2.2 \times 30 \mathrm{~cm}$, Content of each tube;

$8.6 \mathrm{ml}$, Flow rate; $68.8 \mathrm{ml} / \mathrm{hr}$.

Total recovery of protein: $95 \%$.

Total recovery of activity: $87 \%$.

Specific activities (mU/mg) of fractions: RDSC1: 2063, RDSC-2: 2055, RDSC-3: 4704, RDSC-4: 380 . 
Table I. A Typical data in the Process of Preparation of Rice Bran lipase, StaRting With $1 \mathrm{~kg}$ OF DEFATTED RICE BRAN

\section{Step of purification}

\section{Crude extract (Step I)}

Crude enzyme (Step II)

Column chromatography on DEAE-cellulose (Step III)

Gel-filtration on Sephadex G-75 (Step IV)

Column chromatography on CM-Sephadex C-50 (Step V)

Rechromatography on CM-Sephadex C-50 column (Step VI)

\begin{tabular}{|c|c|c|c|c|c|}
\hline $\begin{array}{l}\text { Vol. } \\
(\mathrm{ml})\end{array}$ & $\begin{array}{l}\text { Activity } \\
(\mathrm{mU} / \mathrm{ml})\end{array}$ & $\begin{array}{l}\text { Total } \\
\text { activity } \\
\text { (U) }\end{array}$ & $\begin{array}{l}\text { Protein } \\
(\mathrm{mg} / \mathrm{ml})\end{array}$ & $\begin{array}{c}\text { Specific } \\
\text { activity } \\
(\mathrm{mU} / \mathrm{mg})\end{array}$ & $\begin{array}{c}\text { Over-all } \\
\text { yield } \\
(\%)\end{array}$ \\
\hline 6100 & 127.4 & 777.1 & 13.0 & 9.8 & 100 \\
\hline 935 & 647.1 & 605.0 & 9.14 & 70.8 & 77.8 \\
\hline 3160 & 98.0 & 309.7 & 0.337 & 290.8 & 39.9 \\
\hline 160 & 900.0 & 144.0 & 2.21 & 407.2 & 18.5 \\
\hline 38 & 878.9 & 33.4 & 0.298 & 2949.3 & 4.3 \\
\hline 30 & 926.7 & 27.8 & 0.197 & 4704.1 & 3.6 \\
\hline
\end{tabular}

\section{B. Homogeneity and physical properties of purified lipase}

The homogeneity of the purified enzyme preparation, which appeared to the homogeneous by criterion of CM-Sephadex C-50 column chromatography, was further substantiated by the following physical tests. In addition, the physical properties of the purified enzyme were examined by means of several physical measurement.

Polyacrylamide gel disc electrophoresis. When the purified enzyme was subjected to disc electrophoresis in $7.5 \%$ polyacrylamide gel at $\mathrm{pH} 4.5$, it migrated as a defined band, as shown in Fig. 7, indicating that the enzyme is electrophoretically homogeneous.

Ampholine electrophoresis. The purified enzyme was subjected to ampholine electrophoresis for the determination of isoelectric point. A single peak was obtained at $\mathrm{pH}$ 8.56 on a pH-slope drawn by dotted line in Fig. 8. The experimental result obtained indicates that the enzyme is a homogeneous and basic protein with isoelectric point of 8.56 .

Sedimentation analysis. The purified enzyme solution was dialyzed against $0.01 \mathrm{M}$ phosphate buffer containing $1 \times 10^{-3} \mathrm{M} \mathrm{CaCl}_{2}, \mathrm{pH} 6.2(\mu=$ 0.02 ) at $5^{\circ} \mathrm{C}$ for 3 days under constant stirring, and then concentrated to a final con- 
centration of $0.94 \%$ using collodion membrane filter under reduced pressure. The resulting enzyme solution was ultracentrifuged with a

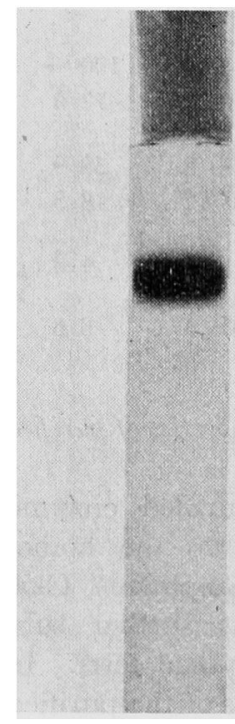

(a)

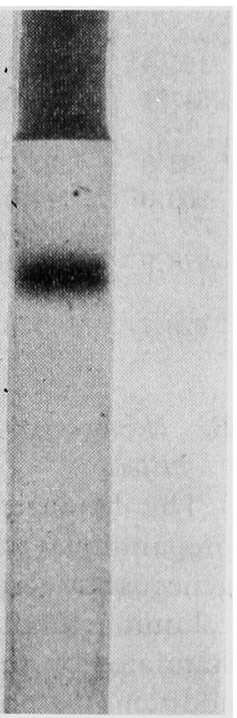

(b)
FIG. 7. Analytical Disc Electrophoresis of Rice Bran Lipase in $7.5 \%$ Polyacrylamide Gel at $\mathrm{pH} 4.5$ with a Current of $2.5 \mathrm{~mA} /$ tube $(0.5 \times 7 \mathrm{~cm})$ for $3.5 \mathrm{hr}$.

(a) Purified enzyme preparation.

(b) Purified and lyophilized enzyme preparation.
Spinco Model E Ultracentrifuge equipped with a synthetic boundary cell, operating at 56,100 $\mathrm{rpm}$ at $20.6^{\circ} \mathrm{C}$. The sedimentation pattern is shown in Fig. 9. The enzyme preparation was homogeneous with a symmetric sedimenting boundary. The sedimentation coefficient, $s_{20 \text {, w }}$ of the enzyme was calculated to be $2.97 \mathrm{~S}$ according to the methods of Schachman ${ }^{131}$ and Svedberg. ${ }^{161}$

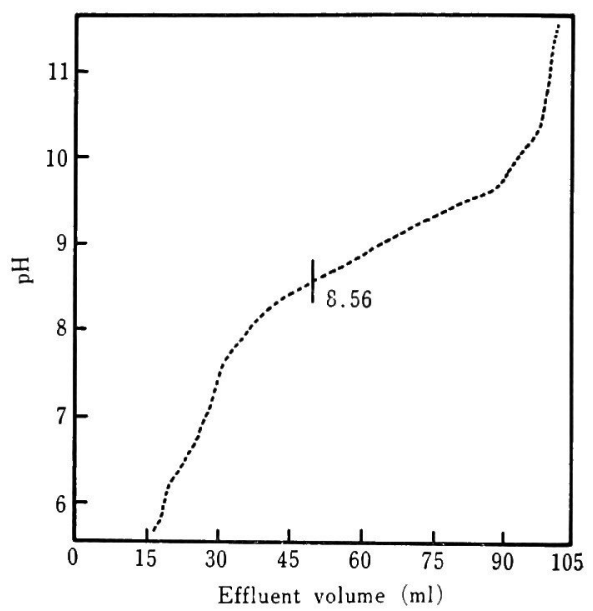

FIG. 8. Ampholine Electrophoresis of Rice Bran Lipase in $0.8 \%$ Carrier Ampholytes $(\mathrm{pH} 7 \sim 10)$ Containing $1 \times 10^{-3} \mathrm{M} \mathrm{CaCl}_{2}$ at $2^{\circ} \mathrm{C}$ for $50 \mathrm{hr}$.

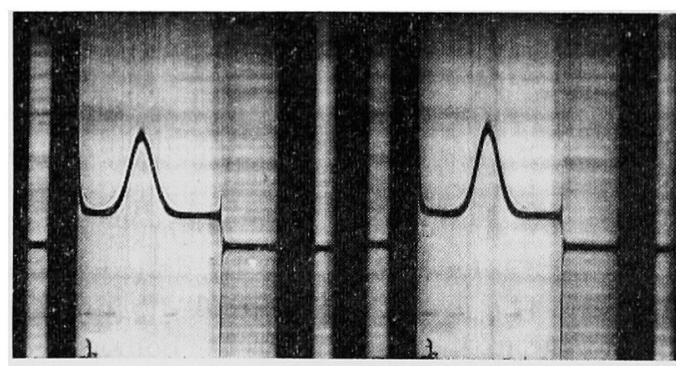

$41 \mathrm{~min}$
$33 \mathrm{~min}$

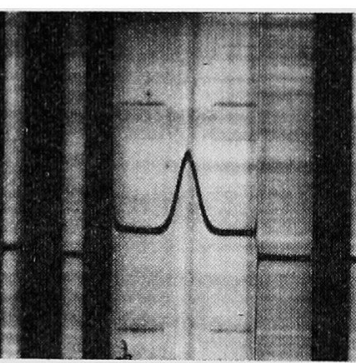

$25 \mathrm{~min}$

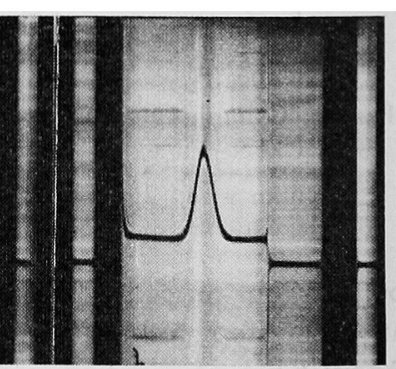

$17 \mathrm{~min}$

FIG. 9. Sedimentaion Patterns of Rice Bran Lipase from a Run in the Synthetic Boundary Cell.

Sedimentaion is from right to left in photographs taken at indicated times after reaching $56,100 \mathrm{rpm}$. Protein concentration was $0.940^{\circ}$ in $0.01 \mathrm{M}$ phosphate buffer containing $1 \times 10^{-3} \mathrm{M}$ $\mathrm{CaCl}_{2}, \mathrm{pH} 6.2: \mu=0.02$. The temperature was $20.6^{\circ} \mathrm{C}$.

16) T. Svedberg and D. K. Pederson, "The Ultracentrifuge," Clearedon Press Inc., Oxford, 1940, p. 445. 
Ultraviolet absorption spectrum. A typical absorption spectrum of the enzyme is shown in Fig. 10; the maximum and the minimum absorptions are found at $278 \mathrm{~m} \mu$ and at $250 \mathrm{~m} \mu$, respectively. The molecular extinction coefficient, $\varepsilon_{280}$ of the enzyme was evaluated to be $7.868 \times 10^{4}$ from the value of $E_{280, \mathrm{~cm}}^{1 \% \%}=19.67$ and the molecular weight of 40,000 which was estimated with Archibald's method described later.

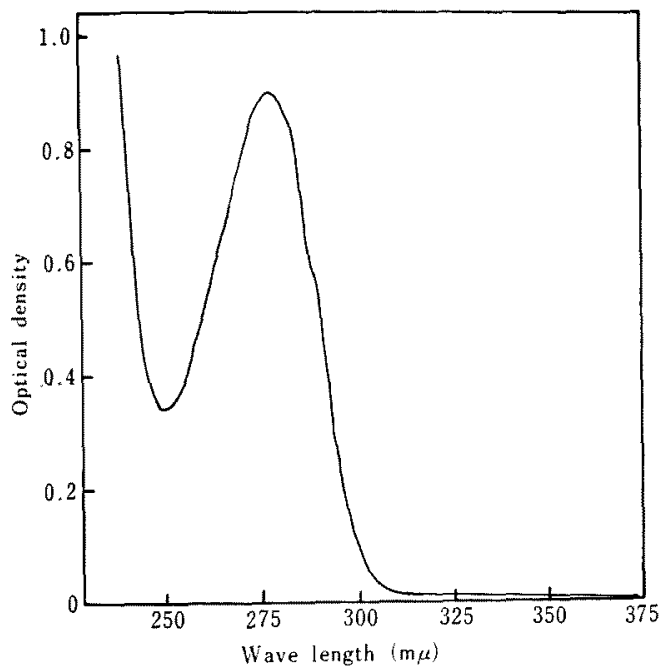

FIG. 10. Ultraviolet Absorption Spectrum of Rice Bran Lipase.

The concentration of the enzyme was $0.441 \mathrm{mg}$ in $1 \mathrm{ml}$ of $0.01 \mathrm{M}$ phosphate buffer containing $1 \times 10^{-3} \mathrm{M} \mathrm{CaCl}_{2}, \mathrm{pH} 6.2$.

Molecural weight. The values of $(d c / d x)_{m} /$ $X m \cdot C m$ and $(d c / d x)_{b} / X b \cdot C b$, which were estimated from photographs of boundary, were plotted against the time after reaching constant revolution and extrapolated to zero-time. From the intercept on ordinate, the values of $\left\{(d c / d x)_{m} / X m \cdot C m\right\}_{t=0} \quad$ and $\left\{(d c / d x)_{b} / X b \cdot C b\right\}_{t=0}$ were found to be 0.803 and 0.835 , respectively. The result is presented in Table II. The morecular weight of the enzyme protein was calculated to be $3.9 \times 10^{4}$ at the meniscus and $4.1 \times 10^{4}$ at the bottom of the cell with an
Table II. Evaluation of $\left\{(d c / d x)_{m} / X m C m\right\}_{t=0}$ AND $\left\{(d c / d x)_{b} / X b C b\right\}_{t=0}$ IN THE Determination of Molecular Weight

\begin{tabular}{ccc}
\hline Time $(\min )$ & $(d c / d x)_{m} / X m C m$ & $(d c / d x)_{b} / \mathrm{XbCb}$ \\
\hline 24 & 0.767 & 0.854 \\
32 & 0.772 & 0.859 \\
40 & 0.763 & 0.849 \\
48 & 0.758 & 0.861 \\
56 & 0.744 & 0.862 \\
Value of extrapolation & & \\
to zero-time & 0.800 & 0.835
\end{tabular}

$X m: 5.98 \mathrm{~cm}, X b: 6.47 \mathrm{~cm}$.

average value of 40,000 .

Optical rotalory dispersion. ORD constant, $\lambda_{e}$, was estimated from the slope which was obtained from Yang's plot shown in Fig 11. A Moffitt-Yang's plot for calculating the Moffitt-Yang parameters, $a_{0}$ and $b_{0}$, is shown in Fig. 12. In this plot, the value of $a_{0}$ is given from the intercept and the value of $b_{0}$ from the slope. The values of $\lambda_{c}, a_{0}$ and $b_{0}$ were $239 \mathrm{~m} \mu,-164$ and -123 , respectively. The values of $a_{0}$ and $b_{0}$ were similar to those of insulin at $\mathrm{pH} 8.5$ or conalbumin at $\mathrm{pH} 5.8{ }^{17}$

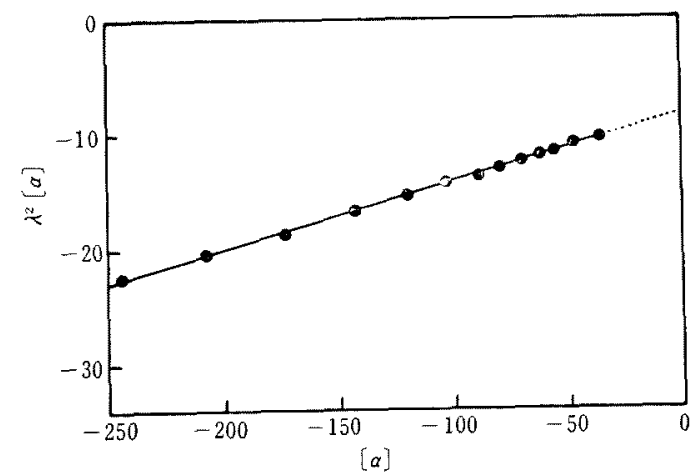

FIG. 11. Yang Plot of Rice Bran Lipase.

The protein concentration was $1.23 \%$ in deionized water. The temperature was $25^{\circ} \mathrm{C}$.

17) "Handbook of Biochemistry," ed. by H.A. Sober, Chemical Rubber Co., Cleveland, Ohio, 1968, p. c.55. 


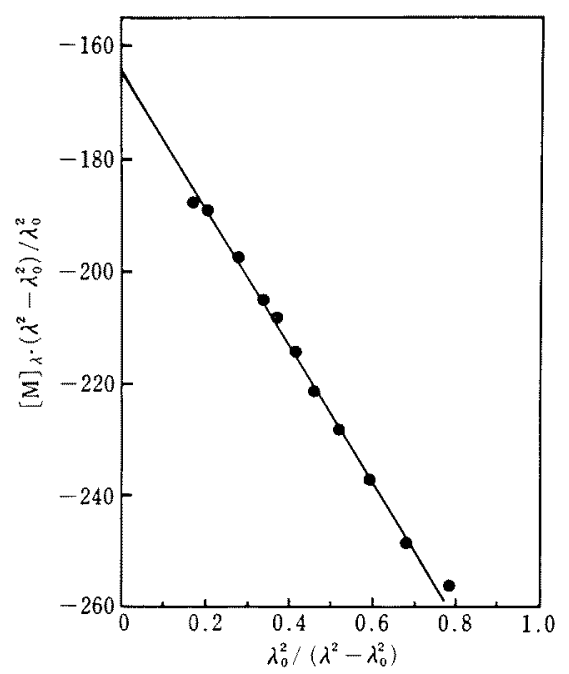

The $\alpha$-helix content of the enzyme was calculated to be around $20 \%$ from the values of $\lambda_{c}$ and $b_{0}$. Discussion on these data will be made in the subsequent paper.

Acknowledgement. The authors wish to thank Professor K. Ito and Dr. K. Tateno, Experimental farm, Faculty of Agriculture, Kyushu University, for the kind supply of rice bran.

FIG. 12. Moffitt-Yang Plot of Rice Bran Lipase.

The protein concentration was $1.23 \%$ in deionized water. The temperature was $25^{\circ} \mathrm{C}$. 